\title{
DINAMIKA KEPEMIMPINAN KEPALA SEKOLAH DALAM MENGEMBANGKAN SEKOLAH EFEKTIF DI SD KANISIUS KADIROJO, SENGKAN, DUWET
}

\author{
Margareta Widiyastuti, Suharsimi Arikunto \\ SMP Katolik Kemasyarakatan, Universitas Negeri Yogyakarta \\ greethspm@yahoo.com
}

\begin{abstract}
Abstrak
Penelitian ini bertujuan untuk mendeskripsikan dan memaknai dinamika kepemimpinan kepala sekolah dalam mengembangkan sekolah efektif di SD Kanisius Kadirojo, Sengkan, dan Duwet. Pengumpulan datanya menggunakan metode observasi, wawancara mendalam, dokumentasi, dan angket. Analisis datanya menggunakan analisis induktif interaktif. Hasil penelitian menunjukkan bahwa dinamika kepemimpinan kepala sekolah sangat bermakna dalam mengembangkan sekolah efektif di SD Kanisius Kadirojo, Sengkan, dan Duwet. Kondisi awal sekolah "memprihatinkan" kemudian mereka mengembangkan menjadi kondisi sekolah saat ini, yang eksis, mampu bertahan hidup, menarik minat masyarakat, bahkan berkembang dalam kualitas, dan sedikit banyak bertumbuh dalam kuantitas. SD Kanisius Kadirojo menjadi sekolah adiwiyata mandiri nasional; jumlah murid stabil; banyak murid berprestasi; dan memiliki kekhasan keterampilan daur ulang. SD Kanisius Sengkan menjadi sekolah yang menarik minat masyarakat; jumlah murid bertambah pesat (tiga parallel); warga sekolah berprestasi dan memiliki kekhasan perikanan lele. SD Kanisius Duwet berhasil menarik minat masyarakat sehingga muridnya terus bertambah; banyak murid berprestasi; dan warga sekolah memiliki keramahan yang spontan.
\end{abstract}

Kata kunci: kepala sekolah, dinamika kepemimpinan, sekolah efektif.

\section{THE PRINCIPAL'S LEADERSHIP DYNAMIC IN DEVELOPING EFFECTIVE SCHOOL IN KANISIUS KADIROJO, SENGKAN, AND DUWET ELEMENTARY SCHOOL}

\author{
Margareta Widiyastuti, Suharsimi Arikunto \\ SMP Katolik Kemasyarakatan, Universitas Negeri Yogyakarta \\ greethspm@yahoo.com
}

\begin{abstract}
This research aims to describe and give meaning the principal's leadership dynamic in developing effective School in Kanisius Kadirojo, Sengkan, and Duwet Elementary School. The techniques of data collection used participant observation, in depth interview, document review, and questionnaire. The data analysis used interactive inductive analysis. The results of the research show that the principal's leadership dynamic in developing effective school is full of meaning in Kanisius Kadirojo, Sengkan, and Duwet Elementary School. At first, the school conditions were very pity, and then they succeeded in developing their school to be effective schools. Their schools exist, able to endure life, attract society interest, even develop in quality, and a little bit more growing in quantity. Kanisius Kadirojo Elementary School has been successful becomes "The National independent Adiwiyata School". It also has stability amount of its student; a lot of students got good achievement from their studying; and also has special skill to recycle material wastes. Kanisisus Sengkan Elementary School has been successful to get some good interest from people around. This school becomes bigger and bigger, and now there are three parallel classes. These conditions can perfectly contribute to gain better people interest. Special achievement from here is cat fish fishery. Kanisius Duwet Elementary School has attractive special achievement from the student's behavior, they are very kind to each other, they have good sense of sympathetic and never bad tempered be seen. A lot of students got good achievement from their studying. By all these good done, the schools can be stabilized their establish going on. Keywords: principal, leadership dynamic, effective school.
\end{abstract}





\section{Pendahuluan}

Pada era tahun 1950-an, sekolahsekolah katolik menjadi sekolah yang hebat karena negara masih miskin dan sekolahsekolah belum terlalu banyak bermunculan. Pada waktu itu, sekolah-sekolah katolik benar-benar dapat menjadi garam yang mengasinkan dan penerang bagi kegelapan karena kebodohan. Sekolah-sekolah katolik terus bertumbuh kembang hingga tahun 1970-an. Sekolah-sekolah katolik dikenal sebagai sekolah yang bermutu; para pegawainya penuh dedikasi, aktif hidup menggereja dan memasyarakat; sarana prasarana lengkap dan lingkungan bersih; warga sekolahnya berdisiplin tinggi dan meraih banyak prestasi; muridnya berlimpah dari berbagai golongan, suku, ras, dan agama.

Sekarang kondisi sangat berbeda, sekolah katolik bukan satu-satunya pilihan masyarakat, sekolah katolik sudah tidak favorit. Sekolah-sekolah negeri semakin banyak dan biayanyapun ringan, bahkan untuk jenjang sekolah dasar dan menengah gratis, sepenuhnya ditanggung negara, sekolah tidak boleh menarik iuran. Di kotakota besar bermunculan sekolah bertaraf internasional dengan bahasa pengantar bahasa Inggris, sarana prasarananya modern dan bermutu global. Sekolah-sekolah katolik tidak siap menghadapi kondisi ini sehingga sekolah katolik menjadi pilihan terakhir. Beberapa sekolah katolik ditutup. Beberapa sekolah katolik tertatih-tatih, hidup enggan mati tidak mau. Akan tetapi ada juga sekolah katolik yang mampu bertahan hidup, bahkan ada beberapa sekolah yang sudah masuk daftar tunggu/akan ditutup mampu hidup, berkembang dalam kualitas, dan bertumbuh dalam kuantitas, serta menjadi sasaran studi banding sekolah-sekolah katolik lainnya.

Informasi sekilas yang diperoleh menyatakan bahwa sekolah-sekolah katolik yang bertahan hidup, berkembang dalam kualitas, dan bertumbuh dalam kuantitas, serta menjadi sasaran studi banding sekolah-sekolah lain dikarenakan oleh kepemimpinan kepala sekolahnya. Kepala sekolah yang mampu mempertahankan sekolah dalam menghadapi tantangan zaman dan kepala sekolah yang mampu mengembangkan sekolah-sekolah yang tadinya sudah masuk daftar tunggu/akan ditutup menjadi hidup dan berkembang/berubah menjadi sekolah diminati masyarakat menarik untuk diteliti dinamika kepemimpinannya.

Penelitian ini berfokus pada dinamika kepemimpinan kepala sekolah dalam mengembangkan sekolah efektif dengan rumusan masalah: "Seberapa baik dinamika kepemimpinan kepala sekolah dalam mengembangkan sekolah efektif di SD Kanisius Kadirojo, Sengkan, dan Duwet." Penelitian ini bertujuan untuk mendiskripsikan dan memaknai dinamika kepemimpinan kepala sekolah dalam mengembangkan sekolah efektif di SD Kadirojo, Sengkan, dan Duwet.

Setiap lembaga/organisasi tidak terlepas dari pemimpin dan kepemimpinan. Dalam buku Kamus Besar Bahasa Indonesia (2008, p. 874), kata pemimpin diartikan sebagai seorang yang memimpin; sedangkan kata kepemimpinan diartikan sebagai perihal pemimpin atau cara memimpin.

Gordon, Aston, \& Snowden (2007, p. 5) berpendapat para teoritikus, para peneliti, dan para praktisi telah mendefinisikan kepemimpinan dalam berbagai cara, Tetapi definisi secara umum dinyatakan oleh Cowley dalam tahun 1920-an: pemimpin adalah seseorang yang berhasil mendapatkan orang-orang lain untuk mengikutinya. Definisi tersebut kemudian dilengkapi lagi dengan membedakan antara pemimpin dengan manajer. Pemimpin adalah orang yang melakukan pekerjaan yang benar. Manajer adalah orang yang melakukan pekerjaan dengan benar (Gordon, Aston, \& Snowden, 2007, p.7). Dengan demikian, pemimpin dapat diartikan sebagai seseorang yang berhasil mendapatkan pengikut untuk mengikutinya melakukan pekerjaan yang benar.

Kepemimpinan didefinisikan beragam. Rost (Sergiovani, 2006, p. 186) mendefinisikan kepemimpinan sebagai hubungan pengaruh antara pemimpin dan pengikut yang mengharapkan perubahan nyata yang mencerminkan tujuan mereka yang sama. 
Kotter (D'Souza, 2007, pp.68-69) mendefinisikan kepemimpinan sebagai menetapkan arah, mengarahkan orang, memotivasi dan mengilhami, dan menciptakan perubahan. Rauch \& Behling (Danim \& Suparno, 2009, p.2) mendefinisikan kepemimpinan sebagai suatu proses yang mempengaruhi aktivitas kelompok yang diatur untuk mencapai tujuan bersama. Lusier \& Achua (2010, p.6) mendefinisikan kepemimpinan sebagai proses mempengaruhi pemimpin dan pengikut untuk mencapai tujuan organisasi melalui perubahan.

Dari beberapa definisi tersebut dapat disimpulkan bahwa kepemimpinan adalah kemampuan pemimpin untuk mempengaruhi pengikut agar berkontribusi dalam usaha mencapai tujuan bersama/organisasi. Dalam lembaga pendidikan kepemimpinan yang dimaksudkan adalah kepemimpinan kepala sekolah untuk mempengaruhi para pegawai (guru dan karyawan) agar berkontribusi dalam usaha mencapai tujuan sekolah.

Mengingat pentingnya peran pemimpin dan kepemimpinan dalam setiap organisasi/lembaga maka banyak kajian tentang kepemimpinan. Yulk (2010, pp. 13-16) menggolongkan teori kepemimpinan dalam lima pendekatan: pendekatan ciri, pendekatan sifat, pendekatan kekuasaan-pengaruh, pendekatan situasional, dan pendekatan terpadu. Robin (2009, pp. 49-58) menggolongkan teori kepemimpinan dalam tiga kelompok: teori sifat, teori perilaku, dan teori kemungkinan. Komives, Lukas, \& McMahon menggolongkan teori kepemimpinan dalam tujuh kelompok: pendekatan orang besar, pendekatan sifat, pendekatan perilaku, pendekatan kontingensi-situasional, pendekatan pengaruh, pendekatan kepemimpinan timbal-balik, dan teori kekacauan. Usman (2011, p. 285) menggolongkan teori kepemimpinan dalam dua kelompok: teori kepemimpinan klasik dan teori kepemimpinan modern. Teori kepemimpinan klasik meliputi gaya kepemimpinan model Mayo, studi Iowa, studi Ohio, dan studi Michigan (Usman, 2011, pp. 285-288). Teori kepemimpinan modern meliputi: teori orang besar, sifat, perilaku, situasional, transaksional, transformasional, dan Pancasila (Usman, 2011, pp. 289-357).

Dari beberapa pendapat tersebut dapat disimpulkan bahwa dalam teori kepemimpinan ada tiga unsur penting: bagaimana seorang dapat menjadi pemimpin; bagaimana mereka berperilaku; dan bagaimana menjadi pemimpin yang berhasil. Bagaimana seorang dapat menjadi pemimpin berkaitan dengan motivasi, kepribadian, nilai, kemampuan, kesanggupan, dan keterampilan. Bagaimana berperilaku berkaitan dengan kegiatan pemimpin dalam posisinya sebagai pemimpin, bagaimana gaya dan perilakunya dalam posisi tersebut. Bagaimana menjadi pemimpin yang berhasil berkaitan dengan proses interaksi antara pemimpin, pengikut, dan situasi/ konteknya.

Kepemimpinan memiliki banyak model. Bush (Usman 2011, p. 373) menyebutkan sembilan model kepemimpinan: manajerial, partisipatif, transformasional, interpersonal, transaksional, postmodern, kontingensi, moral, dan pembelajaran. Lusier \& Achua (2010, pp. 327-362) menyebutkan model kepemimpinan: karismatik, transformasional, transaksional, penata layanan, dan pelayan. Suparno (2013, pp. 26-28) menyampaikan kepemimpinan kristiani sebagai pelayan, gembala, dan pengurus. Lowney (2013, pp. 9-10) menyampaikan kepemimpinan kristiani model Fransiskus, Paus Yesuit yang pertama. Tobroni (2010, pp. 2-5/345) menyampaikan model kepemimpinan spiritual. Indrayana \& Gunawan (2013, pp. 10, 49-50) menyampaikan kepemimpinan berbasis nurani.

Model kepemimpinan beragam, namun tidak ada seorang pemimpinpun meng-gunakan satu model secara utuh/ murni. Pada umumnya dua model atau lebih yang digunakan meskipun ada satu model yang dominan. Model-model yang berkembang di sekolah-sekolah katolik adalah model kepemimpinan pelayan, kegembalaan, kristiani ala Fransiskus, spiritual, dan berbasis nurani.

Kepemimpinan pelayan berpandangan bahwa kita semua mempunyai kewajib- 
an moral untuk melayani satu sama lain, kita harus melayani dan memimpin. Pendekatan kepemimpinan ditandai dengan pelayanan yang kuat dan penekanan moral spiritual (lusier \& Achua, 2010, p. 359). Meyer (D'Souza, 2007, pp. 18-19) menandaskan bahwa para pemimpin yang sangat efektif berhasil karena mereka memandang diri mereka sendiri sebagai pelayan. Pemimpin yang diarahkan oleh nilai menyadari bahwa mempunyai hati seorang pelayan memberikan manfaat luar biasa. Para pemimpin yang memiliki hati seorang pelayan: merasakan diri mereka senantiasa bergairah dengan apa yang mereka lakukan; selalu antusias pada hasil yang diterima oleh para pelanggan dan anggota tim mereka; menantikan hari baru dengan pengharapan besar; selalu membangun organisasi yang aktif; dan selalu dikelilingi oleh anggota tim yang positif dan produktif.

Kepemimpinan kegembalaan merupakan kepemimpinan yang berspiritualitaskan gembala. Kepemimpinan kegembalaan memiliki ciri-ciri: fokus perhatian pada yang dipimpin; pemimpin adalah pelayan bagi yang dipimpin; organisasi dipandang sebagai komunitas manusia; pemimpin memimpin dari depan, menuntun, dan membimbing; pemimpin berani melindungi dan berkorban bagi yang dipimpin; banyak mengupayakan kebaikan orang lain dan mengesampingkan kepentingan sendiri; rela mendelegasikan tugas kepada pengikut dan tetap berani tidak mendelegasikan tugas utama yang menjadi tanggung jawabnya yang utama; peduli mencari anggota yang hilang dan sesat (Suparno, 2013, pp. 26-27).

Kepemimpinan kristiani ala Fransiskus bercermin pada kepemimpinan Fransiskus, Paus Jesuit yang pertama. Fransiskus memiliki enam komitmen dasar memimpin: menjadi diri seperti apa adanya; kekuasaan yang otentik adalah melayani; terlibat dalam kegembiraan dan penderitaan dunia; refleksi; hidup pada saat ini dan menghormati tradisi; tantangan memimpin melalui perubahan (Lowney, 2013, pp. 9$10)$.
Kepemimpinan spiritual merupakan model kepemimpinan komprehensif yang menggabungkan berbagai pendekatan sekaligus sebagai kekuatan penggerak kepemimpinan. Kepemimpinan ini merupakan gabungan kepemimpinan etik, asketik, dan mistik (Troboni, 2010, p.4). Kepemimpinan spiritual oleh Tjahjono (Troboni, 2010, p.4) disebut kepemimpinan dimensi keempat, yaitu kepemimpinan yang lebih mendasarkan pada iman dan hati nurani dalam kualitas kepemimpinannya atau kepemimpinan yang membersihkan hati, memberi, melayani, mencerahkan dan memenangkan jiwa berdasarkan semangat syukur dan kasih.

Kepemimpinan berbasis nurani adalah kepemimpinan yang memandang karyawan sebagai manusia seutuhnya mencakup empat dimensi: tubuh/fisik, pikiran, hati, dan jiwa. Pandangan ini mendukung pemenuhan dasar manusia secara utuh untuk memberikan motivasi total: to live/ bertahan untuk hidup, to love/berhubungan yang erat satu sama lain dengan penuh cinta, to learn/tumbuh dan mengembangkan diri, and to leave a legacy/memberikan nilai dan kontribusi kepada masyarakat, penuh integritas dan memberikan warisan berupa nama yang harum (Indrayana \& Gunawan, 2013, p. 50).

Teori kepemimpinan sangat bermanfaat bagi setiap pemimpin dalam menjalankan peranannya sebagai pemimpin pendidikan. Pemimpin pendidikan (dalam arti kepala sekolah) berperan sebagai personal, educator, manager, administrator, supervisor, social, leader, entrepreneur, and climator (PEMASSLEC) (Usman, 2011, pp. 277-278). Dinamika kepemimpinan kepala sekolah tidak terlepas dari perannya sebagai PEMASSLEC. Untuk dapat melaksanakan perannya, kepala sekolah harus memiliki kecerdasan di atas rata-rata bawahannya. MacGilchrist, et.al. (Usman, 2011, p. 375) mengembangkan sembilan kecerdasan kepemimpinan pendidikan: kecerdasan etika, spiritual, kontekstual, operasional, emosional, kolegial, reflektif, pedagogik, dan sistematik. 
Selain membutuhkan kecerdasan di atas rata-rata bawahannya, kepala sekolah juga membutuhkan perilaku pemimpin atau kepemimpinan yang efektif dalam melaksanakan perannya. Pemimpin yang efektif adalah pemimpin sejati. Karakteristik perilaku pemimpin yang efektif menurut Suseno (2014, p. 81): harus bervisi, bersemangat dan memiliki keberanian, mampu memimpin secara demokratis, dan memiliki integritas. Selaras dengan pendapat Suseno, Gutrie \& Reed (Usman, 2011, p. 296) menyatakan bahwa pemimpin harus memiliki visi, memberi ilham, berorientasi jangka panjang, integritas, memahami dan berorganisasi dengan canggih, dan memelihara keseimbangan dan keharmonisan antara tujuan sekolah dan tujuan individu warga sekolah, serta memelihara bawahan agar betah bekerja sama dengannya. Kepala sekolah dapat melaksanakan kepemimpinan secara efektif jika professional. Seorang kepala sekolah professional antara lain memiliki: kejujuran; kompetensi yang tinggi; harapan yang tinggi; standar kualitas kerja yang tinggi; motivasi yang kuat untuk mencapai tujuan; integritas yang tinggi; komitmen yang kuat; etika kepemimpinan yang luhur (menjadi teladan); kecintaan terhadap profesinya; kemampuan untuk berpikir strategis; dan memiliki pandangan yang jauh ke depan (PPTK, 2011, p. 5).

Secara singkat dapat disimpulkan bahwa kepala sekolah harus memiliki kecerdasan di atas rata-rata bawahan, berperilaku efektif, dan professional agar dapat melaksanakan perannya secara efektif. Kepala sekolah yang melaksanakan perannya secara efektif akan membawa keberhasilan sekolah menjadi sekolah efektif dan ia sendiri menjadi teladan bagi banyak orang.

Cheng (Jande, 2002, p. 45) berpendapat bahwa sekolah efektif adalah sekolah yang menjalankan fungsinya secara maksimal. Sekolah efektif dapat beradaptasi dengan perubahan yang terjadi dalam lingkungannya, baik lingkungan internal maupun eksternal, dan dalam jangka panjang dapat mencapai tujuan-tujuan pendidikan yang diharapkan (Jande, 2002, p. 45). Dengan demikian, sekolah efektif mampu menghadapi tantangan, mengikuti perkembangan, dan memenuhi kebutuhan jaman.

Edmonds (Early \& Weindling, 2004, p. 156) menyebutkan lima ciri sekolah efektif: kepemimpinan yang kuat; harapan yang tinggi untuk prestasi siswa; tersedia iklim yang konduksif untuk belajar; menekankan pada perolehan keterampilan dasar dan frekuensi monitoring kemajuan siswa digunakan sebagai umpan balik. Taylor (Jande, 2002, pp. 46-47) mengemukakan delapan ciri sekolah efektif: tujuan sekolah dinyatakan secara jelas dan spesifik; kepemimpinan kependidikan kepala sekolah kuat; harapan guru dan staf tinggi; ada kerja sama kemitraan antara kepala sekolah, orang tua dan masyarakat; adanya iklim konduksif untuk belajar siswa; kemajuan siswa sering dimonitor; fokus pada keberhasilan siswa dalam mencapai keterampilan aktivitas yang esensial; dan komitmen SDM sekolah tinggi terhadap program pendidikan.

Sekolah dapat dikatakan efektif apabila terdapat kesesuaian dan ketepatan yang bagus antara tujuan dan pencapaiannya. Efektifitas bukan sesuatu yang sifatnya bulat menyeluruh untuk semua aspek. Sebuah sekolah mungkin "efektif sebagian," dalam arti bahwa efektif dan berhasil dalam mencapai tujuan untuk satu atau lebih aspek tertentu tetapi tidak efektif dalam mencapai bidang lain (Depdiknas, 2002, p. 5). Ini berarti sekolah dapat dinyatakan efektif bila memiliki sebagian/beberapa ciri sekolah efektif. Dengan demikian, sekolah efektif tidak harus memenuhi semua ciri sekolah efektif.

Dari beberapa pendapat di atas, dapat disimpulkan bahwa sekolah efektif adalah sekolah yang menjalankan fungsinya secara maksimal sehingga mencapai tujuan yang ditetapkan. Tujuan tersebut berkaitan dengan keberhasilan murid dan menarik minat masyarakat sehingga mampu bertahan hidup, bahkan bertumbuh dalam kuantitas dan berkembang kualitas. Sekolah efektif dalam penelitian ini memiliki ciri-ciri: kepemimpinan 
kependidikan kuat; komitmen pegawai terhadap program sekolah tinggi; memiliki jaringan kemitraan yang kuat; memiliki keunggulan, memenuhi harapan orang tua murid; dan jumlah murid meningkat karena menarik minat masyarakat.

Penelitian kepemimpinan kepala sekolah dasar telah banyak dilakukan oleh kaum akademisi. Beberapa penelitian relevan dengan penelitian ini. Michel, C \& Castle, J.B. (2005) telah meneliti peran kepemimpinan kurikulum kepala sekolah dasar di Selatan Ontario. Para kepala sekolah dasar melaksanakan kepemimpinan pembelajaran melalui komunikasi informal untuk meningkatkan kinerja guru. Para kepala sekolah dasar tersebut menciptakan iklim afektif dan kognitif secara informal untuk menciptakan suasana yang mendukung keberhasilan belajar siswa. Issa, J.H. \& Mustafa, P.O. (2011) meneliti persepsi terhadap kepemimpinan yang didistribusikan dalam pengembangan sekolah. Kepemimpinan yang didistribusikan tampak jelas mendukung/menyumbang pengembangn sekolah. Sebaliknya, bentuk kepemimpinan terkendali/ sentralistik sering mengarahkan ke dalam kerusakan/kemerosotan sekolah. Luttrell, J.L. (2012) meneliti transisi kepemimpinan di sekolah dasar katolik. Transisi kepemimpinan sekolah dasar katolik menuntut kesabaran, dedikasi, dan kelembutan kepala sekolah yang meletakkan jabatan karena dituntut mempersiapkan karakteristik kepala sekolah baru seperti sebelumnya.

Berdasarkan fokus dan masalah penelitian, disusun pertanyaan penelitian sebagai berikut: (1) nilai-nilai apa yang dimiliki oleh Kepala SD Kanisius Kadirojo, Sengkan, dan Duwet sehingga dapat mempertahankan dan menumbuhkembangkan sekolah yang dipimpinnya; (2) bagaimana usaha Kepala SD Kanisius Kadirojo, Sengkan, dan Duwet dalam menumbuhkan sikap percaya diri dan saling menghargai pada para pegawai; (3) bagaimana usaha Kepala SD Kanisius Kadirojo, Sengkan, dan Duwet dalam memotivasi pegawai untuk bekerja optimal; (4) bagaimana usaha Kepala SD Kanisius Kadirojo, Sengkan, dan
Duwet dalam menciptakan budaya positif; dan (5) Seberapa baik dinamika kepemimpinan kepala sekolah dalam mengembangkan sekolah efektif di SD Kanisius Kadirojo, Sengkan, dan Duwet?

\section{Metode Penelitian}

Jenis, Waktu, Tempat dan Subjek Penelitian

Penelitian ini menggunakan metode penelitian kualitatif naturalistik karena penelitiannnya dilakukan dalam kondisi yang alamiah. Metode penelitian kualitatif adalah metode penelitian yang digunakan untuk meneliti pada kondisi objek yang alamiah, di mana peneliti adalah instrumen kunci, teknik pengumpulan data dilaksanakan secara triangulasi (gabungan), analisis data bersifat induktif, dan hasil penelitian menekankan makna daripada generalisasi (Sugiyono, 2013, p. 1). Metode kualitatif dilaksanakan secara intensif, peneliti ikut berpartisipasi lama di lapangan, mencatat secara hati-hati apa yang terjadi, melakukan analisis reflektif terhadap berbagai dokumen yang ditemukan di lapangan, dan membuat laporan penelitian secara mendetail (Sugiyono, 2013, p.10). Metode penelitian kualitatif digunakan karena tujuan penelitian yang ingin dicapai adalah mendeskripsikan dan memaknai dinamika kepemimpinan kepala sekolah dalam mengembangkan sekolah efektif di SD Kanisius Kadirojo, Sengkan, dan Duwet.

Penelitian ini pada awalnya direncanakan selama tiga bulan: Februari - April 2014, namun pelaksanaan diperpanjang sebulan sampai bulan Mei 2014. Penelitian ini dilaksanakan di SD Kanisius Kadirojo, Sengkan, dan Duwet. Tiga sekolah ini dipilih karena sama-sama sekolah Kanisius yang berada dalam satu kabupaten, dalam satu cabang yayasan penyelenggara, dan masih eksis sampai saat ini, bahkan berkembang dalam kualitas dan sedikit banyak bertambah dalam kuantitas.

Subjek dalam penelitian ini adalah Kepala SD Kanisius Kadirojo, Sengkan, dan Duwet; para pegawai (guru dan karyawan) SD Kanisius Kadirojo, Sengkan, dan Duwet; pengurus inti (ketua/wakil) Komite 
SD Kanisius, Sengkan, dan Duwet; wali murid SD Kanisius Kadirojo, Sengkan, dan Duwet.

\section{Prosedur}

Penelitian ini menggunakan proses penelitian kualitatif: orientasi, reduksi, seleksi (Sugiyono, 2013, pp. 16-20). Langkahlangkahnya sebagai berikut: (1) tahap orientasi yaitu mendeskripsikan apa yang dilihat, didengar, dirasakan, dan ditanyakan di SD Kanisius kadirojo, Sengkan, dan Duwet; (2) tahap fokus/reduksi yaitu mereduksi segala informasi yang telah diperoleh di ketiga sekolah tersebut untuk memfokuskan pada masalah dinamika kepemimpinan kepala sekolah dalam mengembangkan sekolah efektif di ketiga sekolah tersebut: menyortir data dengan memilih data yang menarik, penting, berguna, dan baru, kemudian dikelompokkan dalam beberapa kategori yang ditetapkan sebagai fokus penelitian; dan (3) tahap seleksi yaitu menguraikan fokus yang telah ditetapkan menjadi lebih rinci; melakukan analisis yang mendalam terhadap data dan informasi yang diperoleh; kemudian menemukan tema dengan cara mengkonstruksikan data yang diperoleh menjadi suatu bangunan pengetahuan atau teori.

Data, Intrumen, dan Teknik Pengumpulan Data

Data dalam penelitian ini berupa dokumen, kegiatan kepala sekolah, suasana kerja, iklim sekolah, informasi/pendapat dari subjek penelitian. Instrument yang digunakan dalam penelitian ini adalah human instrument, buku catatan, pedoman pengamatan, pedoman wawancara, pedoman pencermatan, dan angket. Buku catatan merupakan catatan harian peneliti dalam kegiatan penelitian untuk mencatat peristiwa/hal penting yang mendukung penelitian. Pedoman pengamatan digunakan untuk mengamati kegiatan kepala sekolah, suasana kerja para pegawai, dan iklim sekolah. Pedoman wawancara digunakan untuk wawancara dengan kepala sekolah, pengurus komite sekolah, guru, dan karyawan (TU, pustakawati, pesuruh, dan satpam). Pedoman pencermatan digunakan untuk mencermati dokumen prestasi sekolah, kedisiplinan, dan perkembangan jumlah murid. Angket digunakan untuk menjaring informasi dari semua guru dan orang tua murid, lebih bersifat untuk mengecek, misalnya: relasi guru dengan kepala sekolah, harapan wali murid, dan lain-lain. Teknik pengumpulan datanya melalui: pengamatan, wawancara, pencermatan, dan angket.

\section{Teknik Analisis Data}

Teknik analisis datanya dilakukan secara induktif. Proses penalarannya dari peneliti datang ke latar penelitian, berada di sana dalam waktu yang memadai, dan menggali masalah menggunakan cara berinteraksi dengan para partisipan yaitu subjek pemilik realitas yang akan diteliti. Jadi, masalah tidak berasal atau diturunkan dari konsep dan teori. Juga tidak berasal dari pemikiran dan kehendak si peneliti, tetapi dari latar penelitian (Putra, 2012 p. 4). Milles \& Huberman (Sugiyono, 2013, pp. 91-99) mengemukakan bahwa aktivitas dalam analisis data kualitatif dilaksanakan secara interaktif dan berlangsung terus menerus sampai tuntas, sehingga datanya sampai jenuh. Aktivitas dalam analisis data yaitu reduksi data, sajian data, dan penarikan kesimpulan atau verifikasi. Langkahlangkah analisis datanya ada dua macam: model mengalir dan interaktif. Model mengalir bila tiga komponen analisis (reduksi data, sajian data, penarikan kesimpulan atau verifikasi) dilakukan saling menjalin dalam proses pengumpulan data dan mengalir bersamaan. Model interaktif bila komponen reduksi data dan sajian data dilakukan bersamaan dengan proses pengumpulan data. Setelah data terkumpul, tiga komponen analisis berinteraksi. Penelitian ini menggunakan model yang kedua, yaitu analisis induktif interaktif di mana tiga komponen reduksi data dan sajian data dilakukan bersamaan dengan proses pengumpulan data. Setelah data ter- 
kumpul, tiga komponen analisis berinteraksi.

\section{Hasil Penelitian dan Pembahasan}

Kepala SD Kanisius Kadirojo, Kepala Sengkan, dan Duwet memiliki nilai-nilai yang menjadi energi positif dalam melaksanakan peran kepemimpinan.

Salah satu peran kepala sekolah adalah sebagai personal/pribadi. Sebagai pribadi, ia harus memiliki integritas kepribadian dan akhlak mulia, pengembangan budaya, keteladanan, keinginan yang kuat dalam pengembangan diri, keterbukaan, dalam melaksanakan tugas pokok dan fungsi, kendali diri dalam menghadapi masalah dalam pekerjaan, bakat, dan minat jabatan sebagai kepala sekolah (Usman, 2011, p. 277). Untuk itu, kepala sekolah harus mengembangkan kecerdasan etika, spiritual, dan emosional (Usman, 2011, p. 377).

Agar dapat memimpin secara efektif, kepala sekolah harus menjadi pemimpin yang efektif. Pemimpin yang efektif adalah pemimpin sejati. Pemimpin sejati berkarakter sebagai berikut: bervisi, bersemangat dan mempunyai keberanian, mampu memimpin secara demokratis, dan memiliki integritas (Suseno, 2014, p. 81).

Karakter atau nilai-nilai tersebut memberikan semangat dan kekuatan batin dalam hidupnya. Nilai-nilai tersebut menjadi spiritualitas baginya. Nilai-nilai tersebut terpancar menjadi energi positif yang ditangkap dan dirasakan oleh orang-orang yang bekerja sama, yang dipercayakan, ataupun yang dijumpainya. Nilai-nilai tersebut tanpa terasa akan mengalir dan dihidupi pula oleh orang-orang di sekitarnya. Kepala sekolah pun terpanggil secara sadar untuk mengalirkan dan menanamkan nilai-nilai tersebut kepada murid-murid yang dipercayakan kepadanya melalui para pegawai (guru dan karyawan). Karena itu, nilai-nilai positif yang dimilikinya harus dirasakan oleh para pegawainya. Nilai-nilai yang telah dirasakan oleh para pegawainya itupun kemudian mereka teruskan dan bagikan kepada para muridnya.
Ketiga Kepala SD Kanisius pun memiliki nilai-nilai yang menjadi spiritualitas dan energi positif dalam melaksanakan peran kepemimpinan. Mereka memiliki nilai yang selaras dengan nilai spiritualitas lembaga, yaitu nilai-nilai Kanisius: kasih, disiplin, cerdas, berani, dan jujur. Nilainilai tersebut mereka hayati dengan penekanan yang berbeda. Dari hasil wawancara menunjukkan bahwa Kepala SD Kanisius Kadirojo lebih mengedepankan nilai beriman, kerja sama, bela rasa, dan peduli. Kepala SD Kanisius Sengkan lebih mengutamakan nilai beriman, bela rasa, dan perhatian personal. Kepala SD Kanisius Duwet lebih menekankan nilai kejujuran dan kasih.

Nilai-nilai yang dihayati kepala sekolah tersebut juga tertangkap dan dirasakan oleh para pegawai dan yang bekerja sama dengannya. Tentu saja, nilai-nilai tersebut terungkap dengan sikap/perilaku yang kurang lebih sama (dapat sama, mirip, atau sedikit berbeda) karena subjek kepala sekolah dan mereka yang menangkap dan merasakan pancaran sikap/perilakunya berbeda.

Nilai kasih ketiga kepala sekolah tersebut terungkap dalam sikap: beriman kuat, visioner, kekeluargaan, sangat melayani, dan sangat komunikatif. Sikap beriman tampak dalam relasi mereka dengan warga sekolah dan dalam kehidupan menggereja. Mereka semua menjadi aktivis gereja di paroki masing-masing dan mendorong para pegawai (guru dan karyawannya) untuk terlibat aktif dalam karya bakti di gereja masing-masing. Sikap visioner tampak dalam reaksi mereka dalam menerima kondisi sekolah yang tidak sesuai harapan mereka sehingga memunculkan idealisme atau cita-cita mereka untuk sekolah tersebut. Sikap kekeluargaan terungkap dalam perilaku: saling percaya, keibuan, bersaudara, adil, kebersamaan, mengampuni, tulus, terlibat.

Meyer (D'Souza, 2007, p. 18-19) menandaskan bahwa para pemimpin yang sangat efektif berhasil karena mereka memandang diri mereka sendiri sebagai pelayan. Pemimpin yang diarahkan oleh nilai 
menyadari bahwa mempunyai hati seorang pelayan memberikan manfaat yang luar biasa. Para pemimpin yang memiliki hati seorang pelayan: merasakan diri mereka senantiasa bergairah dengan apa yang mereka lakukan; selalu antusias pada hasil yang diterima oleh para pelanggan dan anggota tim mereka; menantikan hari baru dengan pengharapan besar; selalu membangun organisasi yang aktif; dan selalu dikelilingi oleh anggota tim yang positif dan produktif.

Sikap sangat melayani tampak dalam relasi mereka dengan warga sekolah. Hasil pengamatan menunjukkan bahwa ketiga Kepala SD Kanisius tersebut sangat melayani dan sangat perhatian. Pada diri Kepala SD Kanisius Kadirojo tampak dalam sikap berdedikasi tinggi, penuh pengurbanan, peduli, menghargai, pengertian, sabar, bela rasa, toleransi, dan sosial. Pada diri Kepala SD Kanisius Sengkan tampak dalam sikap rela berkurban, dermawan, sosial tinggi, semangat berbagi, solidaritas tinggi, pengertian, empati tinggi, loyalitas tinggi, bela rasa, toleran, melindungi, menghargai, mendengarkan, sederhana, kerendahan hati, dan total. Pada diri Kepala SD Kanisius Duwet tampak dalam sikap tanggap, kerendahan hati, menghargai, toleransi, keteladanan, kepedulian, sosial, kesabaran, mendengarkan.

Sikap sangat komunikatif tampak dalam relasi mereka dengan warga sekolah. Hasil pengamatan menunjukkan mereka sangat komunikatif dan sangat terbuka. Kepala SD Kanisius Kadirojo memiliki sikap bersahabat dan ramah. Kepala SD Kanisius Sengkan memiliki sikap ramah, supel, santun, responsif, dan demokratis. Kepala SD Kanisius Duwet memiliki sikap ramah, santun, dan bersahabat.

Hasil pengamatan menunjukkan bahwa ketiga Kepala SD Kanisius tersebut sangat disiplin dan sangat bertanggung jawab. Sikap disiplin ketiga kepala sekolah ini ditangkap oleh warga sekolah dan mengimbas ke seluruh warga sekolah. Warga sekolah menjadi sangat disiplin sehingga terwujud budaya disiplin di sekolah. Sikap disiplin juga tampak dalam kete- gasan, pendirian kuat, konsekuen, taat, dan konsisten.

Nilai cerdas pada diri Kepala SD Kanisius Kadirojo tampak dalam sikap bijaksana, berwibawa, cekatan, kerja keras, dan kerja sama. Pada diri Kepala SD Kanisius Sengkan tampak pada sikap bijaksana, kharisma, kerja keras, kerja sama, kerja tim, dan kompak. Pada diri Kepala SD Kanisius Duwet tampak dalam sikap bijaksana dan kerja sama.

Nilai berani dalam diri ketiga Kepala SD Kanisius muncul dalam sikap yang berbeda-beda. Nilai berani Kepala SD Kanisius Kadirojo tampak dalam sikap kreatif, mengarahkan, suka cita, penuh semangat, pantang menyerah, kemauan keras. Nilai berani Kepala SD Kanisius Sengkan tampak dalam sikap kemauan keras, pantang menyerah, berani mengambil resiko, bersemangat, dan percaya diri. Nilai berani Kepala SD Kanisius Duwet tampak dalam sikap bersemangat, pantang menyerah, dan tidak pernah mengeluh. Selain itu, ketiga Kepala SD Kanisius tersebut memegang teguh nilai kejujuran.

Ketiga Kepala SD Kanisius tersebut memiliki nilai-nilai hidup yang menjadi energi positif dalam melaksanakan peran kepemimpinan mereka sehingga dapat mempertahankan dan menumbuhkembangkan sekolah yang dipimpinnya. Nilainilai yang mereka hidupi ternyata selaras dengan nilai lembaga penyelenggaranya, yaitu nilai-nilai Kanisius: kasih, disiplin, cerdas, berani, dan kejujuran. Meskipun nilai yang dihidupi sama namun manifestasinya tidak persis sama: ada kesamaan, kemiripan, dan sedikit perbedaan.

Usaha-usaha Kepala SD Kanisius Kadirojo, Sengkan, dan Duwet dalam Menumbuhkan Sikap Percaya Diri dan saling Menghargai pada para Pegawai

Sebagai pemimpin, kepala sekolah harus mampu memimpin sekolah dalam rangka pendayagunaan sumber daya sekolah dan harus mampu menjadi teladan bagi guru dan stafnya, serta mengelola sekolah baik sebagai fungsi maupun tugas (Usman, 2011, p. 278). Guru dan karyawan adalah 
manusia dewasa yang terpanggil untuk memanusiakan manusia muda menjadi manusia yang dewasa. Dalam diri mereka dituntut keteladanan, dan keahlian. Bagaimana mereka memberikan teladan jika mereka tidak punya rasa percaya diri? Bagaimana mereka memberi teladan yang baik kalau mereka tidak dapat menghargai orang lain? Karena itu, rasa percaya diri dan saling menghargai harus dimiliki oleh para guru dan karyawan. Rasa percaya diri membantu mereka untuk berani tampil di depan murid dan orang tua murid, berbicara dan berelasi dengan mereka sehingga terjadi komunikasi dan pembelajaran serta kerja sama membantu mendidik manusia muda. Rasa percaya diri juga mendorong rasa percaya pada orang lain. Dengan demikian, membentuk rasa saling percaya.

Para guru dan karyawan yang percaya diri, percaya pada orang lain (saling percaya) dan saling menghargai akan membentuk komunitas pendidikan yang berkualitas dan bermartabat. Karena itu, ketiga Kepala SD Kanisius pun berusaha menanamkan nilai rasa percaya diri dan saling menghargai pada para pegawainya dengan cara yang kurang lebih sama. Persamaannya adalah memberi teladan, kepercayaan, kesempatan, tugas dan tanggung jawab sesuai kemampuan; memberi semangat dan kesempatan mengembangkan diri; dan apresiasi. Perbedaannya sebagai berikut: (1) Kepala SD Kanisius Kadirojo memberi kebebasan yang bertanggung jawab; (2) Kepala SD Kanisius Sengkan membagi pengalaman; memberi kebebasan yang bertanggung jawab; menasehati untuk berpikir positif; dan menyapa serta memberikan refleksi biblis; belajar bersama, saling berbagi, dan saling melengkapi; meminta pendapat dan masukan sebelum memutuskan sesuatu; briefing secara klasikal dan pribadi; dan (3) Kepala SD Kanisius Duwet membimbing/mengarahkan dan membina; melibatkan semua pegawai dalam kegiatan sekolah; tidak membicarakan orang lain; dan mendorong belajar komputer.
Usaha-usaha Kepala SD Kanisius Kadirojo, Sengkan, Duwet dalam memotivasi para pegawai untuk bekerja optimal

Manning \& Curtis (Usman, 2011, p. 290) mengukur kepemimpinan kepala sekolah efektif dengan indikator: berdasarkan fakta, menciptakan visi, memotivasi, dan memberdayakan staf. Usman (2011, p. 296) memberikan kriteria kepemimpinan yang kuat. Kepemimpinan yang kuat mampu mengarahkan, membangkitkan motivasi, dan menyampaikan untuk berbuat baik. Oleh karena itu, seorang pemimpin harus mampu memotivasi para pegawainya untuk bekerja optimal.

Para pegawai di ketiga SD Kanisius tersebut mayoritas tenaga honorer, baik yang diangkat yayasan maupun sekolah. Gajinyapun tidak banyak, sangat jauh dari penghasilan PNS. Tetapi, herannya mereka berdedikasi tinggi dan sangat disiplin. Mereka berusaha melayani para murid dan orang tua murid secara optimal.

Berdasarkan hasil pengamatan, ketiga Kepala SD Kanisius tersebut memiliki nilai sangat melayani, dan para pegawai sangat bersemangat untuk bekerja. Ruparupanya, ketiga Kepala SD Kanisius tersebut sangat menyadari bahwa pelayanan prima yang bermutu kepada para murid dan orang tua murid sebagai pelanggan sekolah sangat penting. Karena itu, mereka meneruskan semangat pelayanan yang tampak dalam sikap sangat melayani kepada para pegawai agar mereka bekerja secara optimal melayani para murid dan para orang tua murid.

Kepala SD Kanisius Kadirojo, Sengkan, dan Duwet memotivasi para pegawai dengan cara yang kurang lebih sama. Persamaannya adalah memberi teladan, nasehat, dan pengarahan; kesempatan dan dukungan; bekerja sama dan melibatkan semua pegawai sesuai kemampuan masingmasing. Perbedaannya sebagai berikut: (1) Kepala SD Kanisius Kadirojo: membangun kekompakan, maju bersama dalam pelayanan; mengingatkan tugas-tugas guru; (2) Kepala SD Kanisius Sengkan: memberi kepercayaan; memberi apresiasi; menjalin 
kedekatan melalui refreshing dan refleksi; menanamkan 3C: conceive, compassion, commitment; memberi kepada guru untuk mendidik dengan hati; dan (3) Kepala SD Kanisius Duwet: terbuka untuk curhat; mengecek dan menegur langsung; mengajak/menugasi guru untuk menghadiri undangan/pertemuan yang memajukan kreativitas guru; menghimbau kuliah S1 untuk memenuhi kualifikasi.

Usaha-usaha Kepala SD Kanisius Kadiroja, Sengkan, dan Duwet dalam menciptakan budaya positif

Salah satu peran kepala sekolah adalah sebagai climator. Kepala sekolah sebagai climator harus menciptakan iklim sekolah yang konduksif (Usman, 2011, p. 278).

Iklim sekolah yang konduksif adalah kondisi yang sungguh-sungguh mendukung proses pembelajaran: para guru dan karyawan krasan dan bekerja dengan penuh semangat melayani para murid dan wali murid secara optimal; para murid pun krasan dan belajar dengan penuh semangat. Kondisi yang demikian disebut juga budaya positif. Dengan budaya positif, diharapkan para murid mencapai prestasi tinggi.

Ketiga Kepala SD Kanisius juga melakukan berbagai usaha untuk menciptakan budaya positif agar pembelajaran terlaksana secara maksimal dan mencapai hasil optimal. Mereka berhasil menciptakan suasana krasan, membangun budaya disiplin dan berprestasi dengan tingkatan yang berbeda.

Dalam hal menciptakan suasana krasan, mereka berhasil menciptakan lingkungan sosial yang penuh kasih persaudaraan dengan menanamkan nilai kekeluargaan dan mengusahakan pelayanan maksimal kepada murid dan orang tua murid. Perbedaannya: SD Kanisius Kadirojo didukung oleh sarpras yang lengkap dan lingkungan fisik yang sejuk dan sehat; SD Kanisius Sengkan didukung oleh sarpras yang memadai; sedangkan sarpras SD Kanisius Duwet yang masih dalam standar minimal, namun keramahan dan sikap welcoming warga sekolah lebih bersifat spontan.
Dalam membangun budaya disiplin, melalui keteladanan dan pengarahan, mereka berhasil membentuk warga sekolah yang sangat disiplin dengan gradasi yang berbeda. Dari data presensi bulan JuliMaret 2014: (1) SD Kanisius Sengkan: presensi murid 98,9\%, guru 99,6\%, karyawan 100\%. (2) SD Kanisius Duwet: presensi murid 98,8\%, guru 99,6\%, karyawan 98,3\% . (3) SD Kanisius Kadirojo: presensi murid 96\%, guru 99,2\%, karyawan 99,8\%. Dari pengembalian angket wali murid: SD Kanisius Duwet 90,8\%, SD Kanisius Kadirojo 86,9\%, dan SD Kanisius Sengkan 79,4\%.

Dalam usaha membangun budaya berprestasi, ketiga kepala sekolah tersebut berhasil. Hal ini tampak dalam hasil pencermatan/analisa dokumen yang menunjukkan bahwa SD Kanisius Kadirojo sangat berprestasi, SD Kanisius Sengkan dan SD Kanisius Duwet cukup berprestasi. Upaya yang mereka lakukan adalah memberi teladan, semangat, kesempatan, memfasilitasi, dan mengapresiasi.

Dinamika kepemimpinan Kepala SD Kanisius Kadirojo, Sengkan, dan Duwet dalam mengembangkan sekolah efektif

Cheng (Jande, 2002, p. 45) menyatakan sekolah efektif adalah kemampuan sekolah dalam menjalankan fungsinya secara maksimal. Slamet PH dalam handout Kapita Selekta Desentralisasi Pendidikan di Indonesia tahun 2005 tanpa nomor halaman berpendapat bahwa sekolah efektif adalah sekolah yang mampu mendidik siswanya mencapai tujuan pembelajaran sesuai dengan jenis, satuan, dan jenjang pendidikan.

Sekolah dapat dikatakan efektif apabila terdapat kesesuaian dan ketepatan yang bagus antara tujuan dan pencapaiannya. Efektifitas bukan sesuatu yang sifatnya bulat menyeluruh untuk semua aspek. Sebuah sekolah mungkin "efektif sebagian," dalam arti bahwa efektif dan berhasil dalam mencapai tujuan untuk satu atau lebih aspek tertentu tetapi tidak efektif dalam bidang yang lain (Depdiknas, 2002, p. 5). Dengan demikian, sekolah efektif dapat diartikan sebagai sekolah yang men- 
jalankan fungsinya secara maksimal berkaitan dengan keberhasilan murid dan menarik minat masyarakat sehingga sekolah mampu bertahan hidup bahkan bertumbuh dalam kuantitas dan berkembang dalam kualitas. Ketiga SD Kanisius ini dipandang sebagai sekolah efektif karena masih eksis, bertahan hidup sampai sekarang, sedikit banyak bertumbuh dalam kuantitas, bahkan berkembang dalam kualitas.

Dinamika kepemimpian kepala sekolah dalam mengembangkan sekolah efektif di SD Kanisius Kadirojo, SD Kanisius Sengkan, dan SD Kanisius Duwet berkaitan erat dengan pelaksanaan peran mereka sebagai PEMASSLEC: personal, educator, manager, administrator, supervisor, sosial, leader, entrepreneur, dan climator. Dalam melaksanakan perannya, mereka menggunakan model kepemimpinan campuran antara kepemimpinan pelayan dan kegembalaan. Hal ini tampak dalam usaha memberikan pelayanan maksimal dan lebih banyak memberikan teladan, pengarahan, bimbingan, ruang gerak, dan mengutamakan pembinaan.

Mereka berhasil mengembangkan sekolah efektif yang bercirikan: kepemimpinan pendidikan yang kuat; komitmen tinggi pegawai terhadap program sekolah; jejaring kemitraan yang kuat; iklim yang konduksif untuk belajar; memiliki keunggulan kompetitif dan komparatif sesuai kekhasan lembaga; memenuhi harapan orang tua; dan jumlah murid meningkat atau minimal stabil.

Usaha-usaha yang mereka lakukan memiliki persamaan dan perbedaan karena mereka sama-sama kepala SD Kanisius di bawah naungan YKCY terletak dalam satu kabupaten dengan karakteristik konteks yang hampir sama dengan visi-misi dan pembinaan yang sama. Yang membuat perbedaan adalah pengalaman dan kreativitas subjek kepala sekolah.

Kepala SD Kanisius Kadirojo adalah pensiunan PNS yang banyak berpengalaman dalam berorganisasi baik di Gereja, masyarakat, dan dinas pendidikan, sangat luwes dalam membangun jejaring dan menggerakkan warga sekolah untuk berprestasi. Beliau mampu membawa SD Kanisius Kadirojo menjadi sekolah adiwiyata mandiri tingkat nasional dan menarik minat masyarakat sehingga sekolah mampu bertahan dan dominan di antara lima SD Kanisius se-paroki.

Kepala SD Kanisius Sengkan dengan totalitas pengabdiannya, mampu memotivasi para pegawai untuk memberikan pelayanan sepenuh hati kepada para murid dan orang tua meskipun gaji mereka jauh di bawah gaji PNS. Pelayanan sepenuh hati menarik minat masyarakat untuk mempercayakan putra-putrinya belajar di sekolah tersebut sehingga SD Kanisius Sengkan bertumbuh pesat dalam kuantitas dan berkembang dalam kualitas.

Kepala SD Kanisius Duwet dengan kerendahan hatinya, belajar kepada mereka yang telah berpengalaman sehingga mampu bekerja sama dengan para pegawai memanfaatkan faslitas yang minimal, memberikan pelayanan maksimal sehingga menarik minat masyarakat. SD Kanisius Duwet pun bertumbuh dalam kuantitas dan berkembang dalam kualitas.

Dinamika kepemimpinan mereka sangat bermakna dalam mengembangkan sekolah efektif di tiga sekolah tersebut mengingat kondisi awal sekolah yang mereka terima sangat memprihatinkan.

Kondisi awal SD Kanisius Kadirojo: “SDM kurang disiplin, sarpras kurang terpelihara, terkesan kumuh. Gedung dan fasilitasnya rusak terkena gempa. Menanggapi situasi itu, saya harus bekerja keras untuk mengubah suasana itu. Saya sendiri bersikap disiplin mulai dari hadir di sekolah sampai selesai mengerjakan tugastugas sehingga dapat mengajak guru-guru untuk disiplin. Bekerja sama dengan berbagai pihak untuk membangun/ merehab gedung dan melengkapinya dengan fasilitas yang diperlukan" (TS, 16/4/2014).

Kondisi awal SD Kanisius Sengkan: "SDM kurang bagus, bahkan saya ditinggali tacika (tabungan cinta kasih) yang tidak beres. Tacika adalah tabungan anakanak dari kelas satu hingga kelas 6 yang disetor ke yayasan, dan pada saat akhir 
tahun kelas enam dikembalikan. Ada selisih keuangan yang banyak antara catatan di buku murid dengan setoran ke yayasan. Dengan kata lain, uang dipakai guru-guru yang bersangkutan. Untuk membereskan hal ini, saya menghentikan tacika selama setahun untuk membereskan dahulu. Dalam hal ini, saya mengeluarkan uang pribadi untuk menutup kekurangan uang murid yang dipakai guru-guru. Guru-guru lama: PNS dpk yang ada, saya dukung untuk menjadi Kepala SDN; GTY pensiun, GTT pindah. Dengan demikian, SDM lama: PNS dpk kembali ke negeri, GTY pensiun, honorer pindah. Sekarang semua sudah tenaga baru, tenaga yang setahun lebih lama dari saya hanya seorang, satu-satunya guru yang mendapat tunjangan sertifikasi dan yang banyak membutuhkan uang untuk pengobatan ibunya. Para guru yang lain berbela rasa menyumbang. Kondisi guru tersebut membantu guru-guru muda untuk tidak tergiur oleh pendapatan dan lebih total melayani murid. Mereka percaya bahwa Tuhan memberikan rejeki yang cukup setiap hari. Hal ini terbagun dari kebiasaan refleksi. SDM yang ada sungguh-sungguh sudah saya kenal sebelumnya karena mereka alumni SD Kanisius dan para mahasiswa PGSD USD yang PPL di sini. Sarpras hanya ada 6 ruang kelas, komputer hanya satu unit pinjaman dari orang tua murid. Untuk mengatasi hal ini, saya bekerja sama dengan berbagai pihak: YKCY (membangunkan gedung unit II dan garasi sepeda motor, Balai Konservasi (memberikan tanaman untuk penghijauan), Orang tua murid (menambah fasilitas)" (MSW, 14/4/2014).

Kondisi awal SD Kanisius Duwet: "Saya merasakan para guru dan karyawan bersikap welcome. Namun saya melihat ada perbedaan status antara guru yang ber-SK Yayasan dan guru yang ber-SK sekolah. Guru-guru yang ber-SK sekolah kurang dilibatkan dalam kegiatan. Murid-murid belum memiliki sikap ramah yang spontan. Wali murid bersikap welcome. Untuk sarpras sangat sederhana, dalam kondisi standar pelayanan minimal. UKS dan perpustakaan belum ada, sarana kegiatan sangat terbatas, halaman gersang. Kondisi tersebut menjadi PR saya, yaitu mengubah mental guru dan murid, serta berusaha melengkapi sarpras yang diperlukan dalam pembelajaran" (CW, 8/4/2014).

\section{Simpulan dan Saran}

\section{Simpulan}

Dinamika kepemimpinan kepala sekolah sangat bermakna dalam mengembangkan sekolah efektif di SD Kanisius Kadirojo, Sengkan, dan Duwet. Dinamika kepemimpinan mereka dapat disimpulkan sebagai berikut.

Kepala SD Kanisius Kadirojo, Sengkan, dan Duwet memiliki nilai-nilai yang menjadi energi positif dalam melaksanakan peran kepemimpinan selaras dengan nilainilai lembaga: kasih, disiplin, cerdas, berani, dan jujur. Namun, ungkapan sikap masing-masing berbeda.

Kepala SD Kanisius Kadirojo, Sengkan dan Duwet menumbuhkan sikap percaya diri dan saling menghargai pada para pegawai dengan cara yang kurang lebih sama: memberi teladan, kepercayaan, kesempatan, tugas dan tanggung jawab, semangat, dan apresiasi; namun perwujudannya sedikit berbeda.

Kepala SD Kanisius Kadirojo, Sengkan, dan Duwet memotivasi para pegawai untuk bekerja optimal dengan cara yang kurang lebih sama: memberi teladan, nasehat dan pengarahan, kesempatan dan dukungan, bekerja sama dan melibatkan semua; namun ungkapan tindakannya berbeda.

Kepala SD Kanisius Kadirojo, Sengkan, dan Duwet menciptakan budaya positif dengan menciptakan suasana krasan, membangun budaya disiplin, dan berprestasi. Mereka berhasil menciptakan budaya positif namun dengan tingkatan yang sedikit berbeda.

Dinamika kepemimpian Kepala SD Kanisius Kadirojo, Sengkan, dan Duwet sangat kuat. Mereka berhasil mengembangkan sekolah yang dipercayakan kepada mereka menjadi sekolah efektif yang bercirikan: kepemimpinan pendidikan yang 
kuat; komitmen tinggi pegawai terhadap program sekolah; jejaring kemitraan yang kuat; iklim yang konduksif untuk belajar; memiliki keunggulan kompetitif dan komparatif sesuai kekhasan lembaga; memenuhi harapan orang tua; dan jumlah murid meningkat atau minimal stabil. Usahausaha yang mereka lakukan hampir sama karena mereka sama-sama Kepala SD Kanisius di bawah naungan YKCY terletak dalam satu kabupaten dengan karakteristik konteks yang hampir sama dengan visi-misi dan pembinaan yang sama. Yang membuat perbedaan adalah pengalaman dan kreativitas subjek kepala sekolah. Mereka melaksanakan peran mereka sebagai PEMASSLEC: personal, educator, manager, administrator, supervisor, sosial, leader, entrepreneur, dan climator dengan menggunakan model kepemimpinan campuran antara kepemimpinan pelayan dan kegembalaan. Hal ini tampak dalam usaha memberikan pelayanan maksimal dan lebih banyak memberikan teladan, pengarahan, bimbingan, ruang gerak, dan mengutamakan pembinaan.

Saran

Dinamika kepemimpinan Kepala SD Kanisius Kadirojo, SD Kanisius Sengkan, dan SD Kanisius Duwet sangat kuat. Mereka berhasil mengembangkan sekolah yang dipercayakan kepada mereka menjadi sekolah efektif sehingga mampu bertahan bahkan bertambah dalam kuantitas dan berkembang dalam kualitas.

Mereka juga berhasil menjadikan ketiga sekolah tersebut unggul dalam bidang non-akademik: pendidikan dasar iman kristiani, pembentukan karakter Kanisus (terutama kedisiplinan), dan pengembangan bakat melaui kegiatan ekstrakurikuler. Namun, masih lemah dalam bidang akademik.

Keberhasilan mereka tentunya tidak terlepas dari faktor pertumbuhan jumlah anak katolik usia SD dan kesadaran umat katolik. Oleh karena itu, mereka harus tetap menjalin relasi yang kuat dengan Gereja; mendorong para pegawai untuk terus- menerus menjadi teladan dalam hidup menggereja dan memasyarakat. Selain itu, mereka harus mengembangkan kompetensi guru untuk meningkatkan mutu akademik.

Penelitian ini masih kurang mendalam sehingga dapat dilanjutkan lagi dengan fokus yang sama di sekolah yang sama namun satu sekolah saja, bukan tiga sekolah supaya dapat mendeskripsikan dan memaknai dinamika kepemimpinan dalam mengembangkan sekolah efektif secara lebih mendalam. Penelitian ini juga dapat diperluas dengan memperhatikan faktor demografi dan tingkat kesadaran umat katolik.

Hasil penelitian ini bernilai transferability, yaitu dapat diterapkan pada sekolah yang memiliki karakteristik/tipologi konteks sekolah yang hampir sama. Dinamika kepemimpinan mereka secara umum juga dapat dicontoh dan dapat mengembangkan kualitas namun tidak menjamin pertumbuhan kuantitas murid jika karakteristik konteks sekolah berbeda.

\section{Daftar Pustaka}

Depdiknas. (2002). Pengembangan sekolah efektif: buku panduan untuk SLTP. Yogyakarta: PPM SLTP.

D'Souza, A. (2007). Proactive visionary leadership. (Terjemahan Trisewu Leadership Institute). Jakarta: Trisewu Nagawarsa.

Early, P. \& Weindling, D. (2004). Understanding school leadership. (1st ed). London: Paul Chapman Publising.

Gorton, R, Alston, J.A, \& Snowden, P. (2007). School leadership and administration. New York: McGraw-Hill Companies.

Usman, Husaini. (2011). Manajemen: teori, praktik, dan riset pendidikan. (Edisi ke-5). Jakarta: Bumi Aksara.

Indrayana, S. \& Gunawan, G. (2013). Manajemen berbasis nurani. Belum diterbitkan. Diakses tanggal 30 Desem- 
ber 2013 dari www.esqu.blogspot. com

Issa, J. H. \& Mustafa, P. O. (2011). Perceptions towards distributed leadership in school improvement. Diakses tanggal 10 Mei 2014 dari http:// dx.doi.org/10.5539/ijbm.v6n10p256

Jande, K. (Ed). (2002). Manajemen pelatihan pengelolaan sekolah. Surabaya: Pearl Surabaya.

Komives, Susan R., Lucas, N \& McMahon, T. R. (2007). Exploring leadership for college students who want to make a difference. United States: A Willy Imprint.

Lowney, C. (2013). Pope Francis: Why he leads the way he leads, lesson from the first Jesuit Pope. Chicago: Loyola Press, a Jesuit Ministry.

Lussier, R. N. \& Achua, C. F. (2010). Leadership: theory, aplication, $\mathcal{E}$ skill development $4 e$. (4th ed). USA: SouthWestern Cengage Learning.

Luttrell, J.L. (2012). When the sisters said farewell: the transition of leadership in chatolic elementary school. Diakses tanggal 30 Desember 2013 dari http://search.proquest.com/docvie $\mathrm{w} / 1112269598$ ?accounted $=31324$

Michel, C. \& Castle, J. B. (2005). The instructional role of elementary school principals. Diakses tanggal 30 Desember 2013 dari http://search. proquest.com/docview/2153712407 ?accounted $=31324$

Putra, Nusa. (2012). Metode penelitian kualitatif pendidikan. Jakarta: Rajawali.

Pusat Bahasa Departemen Pendidikan nasional. (2008). Kamus besar Bahasa Indonesia. (Edisi ke-3). Jakarta: Balai Pustaka

Pusat Pengembangan Tenaga Kependidikan. (2011). Buku kerja kepala sekolah.
Jakarta: PPTK, Badan PSDM dan PMP Kemendiknas.

Robbins, S.P. \& Timothy A.J. (2008). Perilaku organisasi. (Edisi ke-12). Jakarta: Salemba Empat.

Sergiovanni, T. J. (2006). The principalship: a reflective practice perspective. (6 $6^{\text {th }}$ ed). Boston: Pearson Education, Inc.

Slamet, PH. (2005). Handout kapita selekta desentralisasi pendidikan di Indonesia. Jakarta: Proyek Desentralisasi Pendidikan Dasar Direktorat Pendidikan Lanjutan Pertama Departemen Pendidikan Nasional.

Danim, Sudarman \& Suparno. (2009). Manajemen dan kepemimpinan transformasional kekepalasekolahan: visi dan strategi sukses era teknologi, situasi krisis, dan international pendidikan. Jakarta: Rineka Cipta.

Sugiyono. (2013). Memahami penelitian kualitatif. (Edisi ke-8). Bandung: Alfabeta.

Suparno, P. (2013, Juni 6). Kepemimpinan kristiani sebagai pelayan di biara. Rohani nomor 6 Tahun ke-60, 25-28.

Suseno, F.M. (2014). Iman dan hati nurani: gereja berhadapan dengan tantangantantangan jaman. Ed. 1. Jakarta: Obor.

Tim Studi Sekolah Efektif. (2002). Pengembangan sekolah efektif: buku panduan untuk sekolah lanjutan tingkat pertama (SLTP). Yogyakarta: Dinas Pendidikan Proyek Peningkatan Mutu SLTP Provinsi Daerah Istimewa Yogyakarta.

Tobroni. (2010). Spiritual leadership: the problem solver krisis kepemimpian dalam Islam. Diakses tanggal 30 Desember 2013 dari http://tobroni.staff.umm.ac.id.

Yulk, G. A. (2010). Leadership in organization. (7thed). New Jersey: Pearson. 